\title{
Publisher Correction: Comparison of the Hi-C, GAM and SPRITE methods using polymer models of chromatin
}

\author{
Luca Fiorillo (D), Francesco Musella, Mattia Conte (D), Rieke Kempfer, Andrea M. Chiariello (D), Simona Bianco (D), \\ Alexander Kukalev, Ibai Irastorza-Azcarate, Andrea Esposito (D), Alex Abraham (D), Antonella Prisco, Ana Pombo (D) and \\ Mario Nicodemi (D)
}

Correction to: Nature Methods https://doi.org/10.1038/s41592-021-01135-1, published online 7 May 2021.

This paper was originally published under standard Springer Nature license (๔ The Author(s), under exclusive licence to Springer Nature America, Inc.). It is now available as an Open Access paper under a Creative Commons Attribution 4.0 International license, (C) The Author(s). The error has been corrected in the HTML and PDF versions of the article.

Open Access This article is licensed under a Creative Commons Attribution 4.0 International License, which permits use, sharing, adaptation, distribution and
reproduction in any medium or format, as long as you give appropriate credit to the original author(s) and the source, provide a link to the Creative Commons
license, and indicate if changes were made. The images or other third party material in this article are included in the article's Creative Commons license, unless
indicated otherwise in a credit line to the material. If material is not included in the article's Creative Commons license and your intended use is not permitted by statutory regula-
tion or exceeds the permitted use, you will need to obtain permission directly from the copyright holder. To view a copy of this license, visit http://creativecommons.org/licenses/
by/4.0/.
Published online: 3 September 2021
https://doi.org/10.1038/s41592-021-01251-y
(C) The Author(s) 2021

\section{Publisher Correction: Towards resolving proteomes in single cells}

Arunima Singh

Correction to: Nature Methods https://doi.org/10.1038/s41592-021-01243-y, published online 5 August 2021.

In the version of this Research Highlight initially published, the third paragraph, first sentence was unclear. The original sentence read, in part, "Nikolai Slavov and his research group at Northeastern University previously developed SCoPE-MS"; this sentence has been amended to read: "Nikolai Slavov of Northeastern University, along with Bogdan Budnik of Harvard University, and their colleagues, previously developed SCoPE-MS (Single-Cell ProtEomics by Mass Spectrometry) - a single-cell proteomics method that originally made use of carrier cells with isobaric labeled proteins mixed with single cells of interest to reduce sample loss."

The original Research Highlight has been corrected in the online version of the paper.

Published online: 16 September 2021

https://doi.org/10.1038/s41592-021-01298-x

(C) Springer Nature America, Inc. 2021 